\title{
USO DE CORANTES DE ORIGEM NATURAL NO TINGIMENTO DE ARTIGOS TEXTÊIS DE MODA
}

\section{JANICE ACCIOLI RAMOS RODRIGUES, M.SC. | USP MAURÍCIO DE CAMPOS ARAÚJO, Dr. |USP}

\section{RESUMO}

Diante do caos, principalmente ambiental e social, que o planeta terra tem vivenciado, muito tem se falado em sustentabilidade e suas correspondentes estratégias para tentar deter essa situação.

Indo ao encontro da iniciativa supramencionada foi desenvolvido o presente trabalho, cujo objetivo principal foi o de otimizar o uso de corantes naturais amazônicos, no tingimento de tecidos direcionados para produtos de moda, ou seja, trazer pigmentações naturais sem formulações tão agressivas para a aplicação em artigos do vestuário de moda, e, assim, tentar conter, ao menos, em parte, o estrago que a indústria têxtil, uma das maiores poluidoras do meio ambiente, tem causado no mundo.

Para isto, a metodologia aplicada consistiu no cumprimento de quatro etapas, ou seja, pesquisa de dados bibliográficos para servir de referência sobre a temática em questão e para própria a obtenção de pigmentos naturais oriundos de plantas amazônicas, quais sejam, Açaí, Andiroba, Jenipapo, Mamorana, Urucum e Verônica, escolha dos substratos têxteis (tecidos planos PT com ligamento sarja, de algodão $100 \%$ e tecido meia-malha composto por $98 \%$ algodão e $2 \%$ elastano), selecionados de acordo com a afinidade, após os testes com os extratos corantes, análise da potencialidade de aplicação dos corantes nos substratos estudados (verificação do índice de solidez dos corantes à lavagem e à luz) e produção de uma cartela de cores, uma coleção e artigos de vestuário com os tecidos tingidos com alguns dos corantes estudados.

Como principais resultados deste trabalho obtiveram-se corantes que, na interação com as fibras, provocaram tingimentos uniformes, os materiais corantes foram utilizados em pouca quantidade, composição química inserida nos padrões sustentáveis, poucos resíduos expelidos nas sobras dos banhos de tingimento, uma cartela de cores variadas (Figura 1), boa solidez às lavagens e à luz, 0 planejamento de uma coleção de roupas e quatro peças das mesmas confeccionadas, com a aplicação dos corantes naturais, o que conferiu aos extratos corantes a qualidade de sustentáveis. 
